\title{
Communication \\ Sets of Sustainable Development Indicators in Vietnam: Status and Solutions
}

\author{
Tri Ngo Dang, Chi Tran Thuy, Y. Tran Van and Tuan Nguyen Thanh * \\ Department of Geography, Pedology and Environment, Vietnam National Museum of Nature, \\ VAST, Hanoi 10000, Vietnam; ngodangtri@gmail.com (T.N.D.); chitranthuy51@gmail.com (C.T.T.); \\ ytranvan@yahoo.com (Y.T.V.) \\ * Correspondence: legis_tuan@vnmn.vast.vn; Tel.: +84-967-248-168
}

Received: 21 October 2017; Accepted: 12 December 2017; Published: 25 December 2017

\begin{abstract}
There are some sets of sustainable development indicators (SDIs) at different regional scales and the Millennium development goals indicators (MDGIs) and Sustainable Development Goals (SDGIs) are employed in Vietnam. Actually, building and applying SDIs have faced different difficulties and this has led to a reduction in their value. Solutions to improve SDIs have been proposed and completed. This paper aims to review the SDIs, MDGIs, and SDGIs in Vietnam and to propose recommendations for building and effectively applying them in practice in Vietnam. Two national SDIs, one regional SDI, one local SDI, and some provincial SDIs, in addition to the results of MDGIs/SDGIs implementation, were analyzed. The common limitation of Government promulgated SDIs was found to not be feasible as they are applied in practice. Proposed solutions are building pilot SDIs for specific regions in Vietnam based on UN guidelines from 2007 and calculating practical values of SDIs for pilot regions, subsequently recommending relevant authorities in Vietnam to change or adjust promulgated SDIs. The experiences of procedure used to develop the pilot SDIs and effective handing over the usage of SDIs to stakeholders should also be considered when developing the sustainable development goals indicators in the future.
\end{abstract}

Keywords: sustainable development indicators; tracking; monitoring; assessing; Vietnam

JEL Classification: Q01

\section{Introduction}

Sustainable development indicators have five main functions: (1) leading to better decisions and more effective actions; (2) allowing incorporate natural and social science knowledge in decision-making; (3) allowing measure and calibrate progress toward sustainable development goals; (4) providing an early warning on economic, social, and environmental issues; and (5) communicating ideas, thoughts, and values (UNCSD 2007). It was recognized that the above important functions in Agenda 21 (United Nations 1992) of the United Nations called on countries and international organizations to develop and use sustainable development indicators (SDIs). In response to the call, many organizations and countries made efforts to develop SDIs and they became an effective tool for assessing progress toward sustainable development (Peterson 1997). There are many SDIs which have been developed around the world and according to the International Institute for Sustainable Development (IISD 2017), there are 900 publications related to SDIs on the website of Compendium of sustainable development indicator initiatives.

With respect to SDIs, the Commission on Sustainable Development (CSD) adopted three editions of Sustainable Development Indicators Guidelines and Methodologies (SDI GM), which guides countries/locals to develop their own indicator sets. In 1996, CSD adopted the first edition of SDI GM. This 'blue book' guides SDI selection based on a causal conceptual framework with 134 indicators 
(UNCSD 1996). But after the testing of these indicators in several countries, the framework was abandoned as it was found to be inappropriate for economic and social indicators and it lacked focus on policy (Nathan and Reddy 2008). Therefore, the blue book was revised and the second edition of SDI GM was presented in 2001. This edition used the pillars/dimensions framework with 58 indicators, 15 themes, and four dimensions (social, economic, environmental, and institutional) instead of a causal framework (UNCSD 2001) as they are the foundation of sustainable development. In 2007, the newest edition of SDI GM was published. In this edition, the division of indicators along the lines of four dimensions (social, economic, environmental, and institutional) is no longer explicit, but is based on a domains framework. This change emphasizes the multi-dimensional nature of sustainable development and reflects the importance of integrating its pillars (UNCSD 2007). This approach makes it easier for stakeholders to comprehend the issues, and aids decision making about sustainable development (Lock 2006). At the same time, it does not prevent the linking of indicators or domains to dimensions of sustainable development as a pillar framework (Côté and McCollough 2007). The SDIs framework includes 96 indicators belonging to 14 themes.

With respect to the Millennium Development Goals Indicators (MDGIs), in 2001, the United Nations Statistic Office developed the MDGIs to track the progress made towards meeting the Millennium Development Goals in all states. The timeline to achieve the goals was 2015 (Maya et al. 2013). The MDGIs developed the goals-based framework and 48 indicators were grouped on eight goals with 18 targets released by the UN. In 2007, the MDGIs were updated to four targets and 10 indicators. The limitations of MDGIs were indicated by many authors and summarized by Maya et al. (2013). These are limitations in the Millennium Development Goals (MDG) development process, the MDG structure, the MDG content, the MDG implementation and enforcement. In order to correct these MDGIs shortcomings, the SDGIs were designed to substitute the MDGIs in 2015. They include 232 indicators to track and evaluate the implementation of 17 goals and 169 targets to 2030 (UNSC 2017). Besides the addition of goals, targets, and indicators, targets which were proposed are stricter, for example, the target of reducing poverty to 50\% has been substituted with "By 2030, eradicate extreme poverty for all people everywhere". The goals are uniformly applicable to all countries of the world, removing the "developing" versus "developed" dichotomy that left the MDGs open to criticism (ICLEI 2015).

Why is there parallel development? The SDIs are used to track progress towards national sustainable development/territorial regions, and to track, monitor, and assess a national/territorial sustainable development strategy, while MDGIs/SDGIs were developed for the global monitoring of progress toward meeting globally established goals (UNCSD 2007). Both of them are designed to make policies toward sustainable development started by the UN. The SDIs cover a broad range of issues intrinsic to all dimensions of sustainable development including economic development, social development, and environmental protection. On the other hand, the SDGIs are specific to the seventeen SDGs, and have a more limited coverage. For example, the SDGIs lack indicators related to demographics and MDGIs did not cover issues such as demographics, natural hazards, governance, and macroeconomics before. Thus, two indicator sets are used for the different purposes and complement each other.

Along with the development of SDIs, MDGIs, and SDGIs, there are some Vietnam SDI sets designed based on adapting the CSD indicators to national/local conditions and the Vietnam's SDGIs (VSDGIs) have been developed. This paper aims to review the SDIs and MDGIs/SDGIs in Vietnam and propose recommendations on developing and effectively applying them in practice in Vietnam. Since the adoption of the United Nations Millennium Declaration in 2000, the SDIs and the Millennium Development Goals Indicators (MDGIs) have been developed in parallel (Figure 1). 


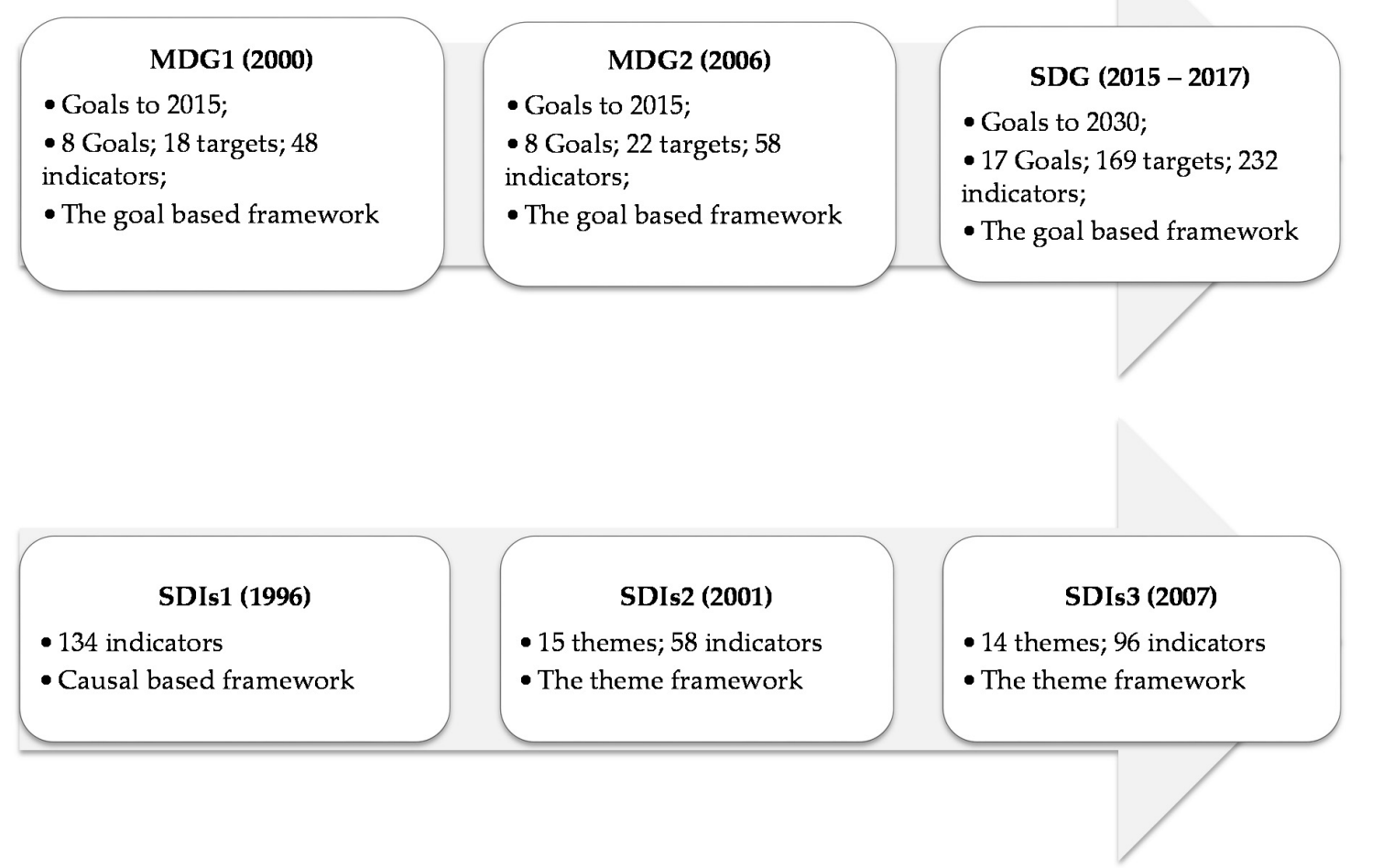

Figure 1. Evolution of sustainable development indicators and sustainable development goals indicators.

\section{Methodology}

In order to consider the advantages and disadvantages of sets of sustainable development indicators issued in Vietnam, they were compared with the SDIs framework of the UN established in 2007. The cover of indicators ranged over the spectrum of sustainable development issues and their replication was indicated along the way. Additionally, based on guiding and applying the indicator sets to track, monitor, and assess sustainable development in Vietnam up to now and the achieved results, their feasibility when used in practice was evaluated.

\section{Sustainable Development Indicators and Sustainable Development Goals Indicators in Vietnam}

\subsection{Sustainable Development Indicators}

Based on SDI GM (1996), in 1998, the first draft set of SDIs in Vietnam was promulgated by the Vietnam Environment Administration. The set included 80 indicators which relied on the causal-based/linkage-based framework and classified them into pressure-state-response groups belonging to three pillars: (1) socio-economic (three economic and seventeen social indicators); (2) environment (seven soil, five inland water, four sea, and six air environment indicators, and three solid waste, eleven biodiversity, and eight environmental incident indicators); and (3) environmental management with sixteen indicators. Obviously, the set was inclined to the environmental pillar (60/80 indicators), while the socio-economic indicator was not properly considered (20/80 indicators). Finally, the set was not promulgated officially.

In 2003, a scientific group from the Vietnam Union of Science and Technology Associations proposed a SDI set grounded on the causal-based/linkage-based framework. The set consisted of 42 indicators belonging to four pillars: 5 economic, 16 social, 17 environmental, and 4 response indicators. Subsequently it was reduced to 25 indicators including 4 economic, 9 social, 10 environmental, 
and 3 responses. Although the environmental indicators had decreased, the economic ones still occupied a low ratio. This means that the set had not been balanced and harmonized between the pillars. Like this, the United Nations promulgated the second edition of SDI GM in 2001, and the set was based on the theme framework.

Based on the second edition of SDI GM, some provinces of Vietnam (Ninh Binh, Lam Dong, Quang Nam, Thai Nguyen, and Yen Bai) applied the theme-based framework, including three pillars, to put the sets of SDIs in their own sustainable development strategies of 2006-2010 in 2005 (Lam Dong Provincial People's Committee Lam Dong; Ninh Binh 2006; Quang Nam 2006; Thai Nguyen 2006; Yen Bai 2006). Although five sets were proposed by the provinces, no documents were promulgated.

UNDP and the Ministry of Planning and Investment published the document "Designing a set of SDIs and building a database for monitoring sustainable development in Vietnam" in 2006. The set relied on the SDI GM in 2001. The document is an important result of the project "Implementation of Vietnam Agenda 21-VIE/01/021" (UNDP and MPI 2006). The set was designed at a national and provincial scale. Nationally, the set was composed of 44 indicators: 12 economic, 17 social, 12 environmental-resource, and 3 institutional, while provincially, 30 indicators (7 economic, 14 social, 6 environmental-resource, and 2 institutional) were proposed (Table A1). Software for managing an indicator database was developed to support the tracking and monitoring of sustainable development.

In 2012, the Vietnamese Prime Minister promulgated decision no 432/QĐ-TTg dated 4th December 2012 on the Vietnam sustainable development strategy period 2011-2020. Following this, a set for monitoring and assessing Vietnam sustainable development period 2011-2020 was approved. It consisted of 3 composite, 10 economic, 10 social, and 7 environmental-resources indicators (Table A2). This was an important step forward in terms of designing a set of SDIs since it was the first time a set of SDIs was promulgated officially by the Government.

At the end of 2013, the Vietnam Prime Minister promulgated a set of SDIs for monitoring and assessing sustainable development in provinces for the period 2013-2020 to make a united legal basis. This resulted in a united and transparent information system from a national to provincial scale to monitor and assess the progress of the implementation of the Vietnam sustainable development strategy (VPM 2013a). The set was designed based on the indicators for monitoring, and assessing national sustainable development and provincial statistic systems, and made sure it closely targeted the development priorities of the Vietnam sustainable development strategy. The indicators were classified into two groups: common and local characteristics. The common indicators included 28 variables: 1 composite, 7 economic, 11 social, and 9 environmental-resource, while the local characteristic group had 15 indicators ( 1 indicator for mountainous regions, 2 for plains, 2 for coastal areas, 5 for national cities, and 5 for rural regions) (Table A3). Both the government promulgated sets of SDIs did not inherit the theoretical framework of the set of SDIs proposed by the project VIE/01/021.

There is some research on the design of recent SDIs. For example, (Hai et al. 2009, 2013) developed the SDIs for Quang Tri and Thai Binh province based on a procedure with two steps: (1) proposing a draft of SDIs relying on the theme framework inherited from Indonesia, Thailand, China, and England, as part of the project VIE/01/021; (2) using the Delphi method to finalize the SDIs in 2009 and 2013. However, the SDIs only had a list of indicators and there was no calculation for each indicator; therefore, the feasibility and applicability had not been validated. (Tran Van et al. 2016) carried out a full procedure for designing a set of SDIs to monitor and assess sustainable development in Tay Nguyen's provinces. This included designing the indicator framework that was suitable for Tay Nguyen at three scales (77 regional, 70 provincial, and 48 district indicators) (Table A4), collecting data for each indicator; defining target values; calculating, measuring, and assessing the sustainable development; proposing solutions for each section and scale; and developing a software for managing data, supporting the calculation of indicators, and viewing the results. The SDIs were developed based on the theme framework of UNCSD (2007). The first proposed indicators selected relied on seven criteria: (1) be appropriate with the point of view on sustainable development strategy 
2011-2020; (2) suitable for the United Nations SDIs and cover a broad range of sustainable development issues; (3) indicators ensure independence and relative balance between themes; (4) suitable for the Tay Nguyen development strategy; (5) inherit selectively sustainable development indicators; (6) have indicators reflecting the Tay Nguyen characteristics; (7) ensure calculation feasibility, it means that the real value of each indicators can be calculated based on statistic indicators system or feasible methods. After the selection of proposed SDIs was completed, they were given a suggestion by provincial managers to finish the proposed SDIs. Sequentially, they were assigned scores ranging from one to five based on their reflection of sustainable development in Tay Nguyen by think tanks who deeply and widely understand sustainable development. Finally, the proposed indicators were processed by the Delphi method to finalize the Tay Nguyen SDIs.

\subsection{The Millennium Development Goals and Sustainable Development Goals Indicators}

After the Millennium Declaration was approved and the commitment was made to implement the Millennium Development Goals (MDGs) in 2000, Viet Nam immediately initiated the implementation process. In 2005, Vietnam had begun developing database systems for 48 MDGIs and 35 Vietnam Development Goals indicators (VDGIs) proposed by the Vietnam Government. Vietnam established 12 development goals of its own which focused on social and poverty reduction goals, in which there were four VDGs (GSO 2005; VN 2015). VDGs fully reflected MDGs and took into account Vietnam's own characteristics and national aims. Some additional sectors were included and stressed in the VDGs such as good governance, reducing gaps between ethnic groups and infrastructure. The VDGs were integrated widely and effectively into national socioeconomic development strategies and further broken down in detail. For example, at the beginning of the implementation process, they were mainstreamed into the Agenda 21 framework, and in the latter years, the VDGs have been integrated into the country's socio-economic development strategy for the period 2011-2020 and the five-year socio-economic development plans. In order to accelerate the realization of the MDGs in the end stage of MDGs, some legal documents were issued, such as Government Resolution 05/NQ-CP on accelerating the implementation of the MDGs for the Health Sector on 13 January 2014 and the "Framework Plan to promote MDGs for ethnic minorities linked to the post-2015 SDGs" (VPM 2014).

In order to monitor and evaluate the implementation of MDGs, MDGIs were integrated into the national statistical indicators system to ensure that the collection of data was harmonized and timely. Legal documents relating to the collection of data on the MDGs such as Decision No. 1755/QĐ-TTg on "Principles and tasks for reporting on the implementation of MDGs" and major reforms in the statistical field as stated in the "Strategy for statistical development in Viet Nam for 2011-2020 and the vision until 2030" created a stepping-stone for comprehensive improvement of the collection of data on the MDGs (VPM 2013b).

According to the country report on 15 years achieving the Vietnam Millennium Development Goals in 2015, the MDGs which Vietnam achieved were: MDG 1: Eradicate Extreme Poverty and Hunger, MDG 2: Achieve Universal Primary Education, MDG 3: Promote Gender Equality and Empower Women, and MDG 5: Improve Maternal Health. One which was nearly achieved was MDG 4: Reduce Child Mortality. The remaining ones which were partially achieved were MDG 6: Combat HIV/AIDS. Malaria and Other Diseases, MDG 7: Ensure Environmental Sustainability, and MDG 8: Global Partnership for Development.

After the sustainable development goals (SDGs) were approved in 2015, Vietnam Agenda Office 21 organized several conferences to report and review SDGIs in Vietnam such as the conference on implementing SDGs: Emphasizing natural capital in the Greater Mekong Subregion (GMS) (Tuan 2015), the report reviewed 17 goals and 169 targets in the Agenda 30 for sustainable development in Vietnam, providing bases for the nationalization of global SDGs (VPPTBV 2016). Legally, in order to implement Agenda 2030, the Vietnam Prime Minister approved the national action plans in 2017 (VPM 2017). The decision mentioned development and issue of the Vietnam sustainable development indicators (VSDGIs). This means that VSDGIs have been developing until now. 


\section{Discussion}

In order to implement Vietnam sustainable development goals, the Vietnam government has promulgated legal documents since 1998, and some departments and provinces have also concretized the documents. The legal system of sustainable development, improving the quality for governance for sustainable development, has continued in its formulation. Accompanying this have been sets of SDIs for monitoring and assessing sustainable development, completing this both theoretically and practically.

The implementation of sustainable development in Vietnam has been integrated into socio-economic and branch development plans and strategies. Specifically, global principles and goals of sustainable development have concretized Vietnam conditions and integrated them into provincial socio-economic and branch development plans and strategies (MPI 2005; VN 2012; MPI 2013). However, the set of SDIs for monitoring and assessing Vietnam sustainable development was officially promulgated in 2011 (VPPTBV 2014; Tran Van et al. 2016).

Two official sets of SDIs have faced difficulties when they have been applied, although the guidelines were released. Both were proposed based on three pillars: economic, social, and environmental, as well as the composite indicators. They were not based on any theoretical framework and thus there was replication in these sets. More specifically, in the set of SDIs for the period 2011-2020, the "Environmental sustainable development composite indicator" is calculated based on indicators such as air quality, biodiversity, and soil and water quality. Thus, there is partial replication between the composite and other indicators such as air quality. Furthermore, calculation of the composite indicator is not easy and nowadays it is not used and calculated (Lam 2015). This is why the target values of 2015 and 2020 were not mentioned in the set. Additionally, the target values of indicators: "Ratio of protected, biodiversity maintaining areas"; "Degraded land areas"; and "Ratio of days with harmful substances in the air above standard" have not been taken into consideration. This reflects the infeasibility of data for calculation, which leads to a reduced practicability of the set of SDIs.

The absence of indicators related to Vietnam seas and islands in both sets of SDIs is an extremely important shortcoming, although Vietnam is one country with large sea areas and these indicators were also mentioned in the SDI GMs in 2007. No mention of target values in the set of SDIs at a local scale for the period 2013-2020 is an area of concern. Tracking and evaluating the progress toward sustainable development are not implemented for the whole inlands and territorial waters of Vietnam. Application of the local set of SDIs in practice has faced many difficulties, too. For instance, when applied for the North West provinces, only one of the second set of indicators was calculated because no data could be collected (Vuong 2016). This shortcoming reflects the lack of consideration of available data in the design of the SDIs. The infeasibility of data can be for two reasons: firstly, ineffective training of staff; and secondly, metrics cannot be calculated by normal statistic methods or by the Vietnam official statistic system, or are calculated with high costs.

With respect to technical support, two sets of SDIs promulgated by the Vietnam Government have no tools and database to support calculation. Tracking, monitoring, and assessing needs to be managed in a system including a database, software tools to calculate indicators, and viewing tools to analyze the sustainable development progress of the nation, localities, or regions. This shortcoming has also made it difficult to implement the sets in practice.

In the period 2004-2011, three provinces: Thai Nguyen, Quang Nam, and Lam Dong, promulgated provincial sets of SDIs, but with no guidelines. Through 12 workshops in 12 North Western provinces, almost all responsible offices said there have been no guidelines for calculating and reporting the set of SDIs for monitoring and assessing the sustainable development in provinces for the period 2013-2020. The set for monitoring and assessing Vietnam sustainable development period 2011-2020 has no guidelines for calculating and reporting, too. This created barriers for tracking, monitoring, and assessing sustainable development in the provinces.

With respect to organization, the National Sustainable Development Council was founded in 2005 following decision No 1032/QĐ-TTg of the Vietnam Prime Minister, dated 27 September 2005 
(VPM 2005). The council consults with the Vietnam Prime Minister to direct the implementation of the sustainable development strategy of Vietnam, and tracks, monitors, and evaluates the implementation of sustainable development goals and targets in Vietnam following approved sustainable development strategies. The sustainable development offices have been found in some ministries and departments, and The Business Council for sustainable development has also been established in Vietnam (VN 2012). Thus, the strengthening of organizations needs to be continued because there are only sustainable development offices in some provinces. This is a remarkable shortcoming for the implementation of sustainable development plans for provinces in general, applying sets of SDIs in particular, although some training has already been carried out (VPPTBV 2013).

As mentioned in the analysis, a comprehensive set of SDIs meets three aspects: firstly, a framework of SDIs including name, definition, meaning, and calculation of each indicator; secondly, real, target/threshold values of SDIs; and thirdly, an information system of SDIs including a database and software. In the future, the very important results of the Tay Nguyen set of SDIs can guide change, although it is only a study, not a legal framework. The set was designed based on a clear theoretical framework with a full consideration of data availability of indicators, and assures comprehensive, full monitoring of themes of sustainable development and local characteristics. This is the unique SDI set implementation which developed software to manage a database and support for calculations. Although it still has some limitations such as: (1) a design limited to Tay Nguyen, not all Vietnam provinces; and (2) the target values of provinces have not probably been reached, but this promising approach will bring advantages for tracking, monitoring, and assessing the progress toward sustainable development in Vietnam.

Consequently, there are both MDGIs and SDIs which have coexisted in Vietnam since 2012. They have been used for two different purposes. Vietnam used 48 MDGIs and developed 35 VDGIs to monitor the MDGs implementation in the Millennium Declaration. Additionally, the SDIs have been used to monitor and assess the Vietnam sustainable development strategy for the period 2011-2020 and the sustainable development in provinces for the period 2013-2020.

\section{Conclusions}

SDIs and MDGIs/SDGIs are employed for two different purposes, and do not conflict with each other. They could complement each other if the relationship between them and national/territorial region characteristics are taken into consideration when developing them.

National and local sets of SDIs and VSDGIs have gradually been developed scientifically, practically, and legally. The strengthening of organizations to implement tracking, monitoring, and assessing sustainable development through sets of SDIs and MDGIs/SDGIs has also developed step by step and enhanced capacity. The Vietnam government promulgated two sets of SDIs (national and local); however, they have still had very important shortcomings: the absence of indicators related to sea and islands, a low feasibility, and the replication of composite indicators. The reasons which lead to the shortcomings result from the fact that the lack of a necessary theoretical framework, the availability of data to calculate values of indicators, and the training have not properly been taken into consideration when designing sets of SDIs. Both national and local sets of SDIs have not had technical tools (Information Technology) to support the tracking, monitoring, and assessing of progress toward sustainability. The Tay Nguyen set of SDIs is a new and important advance for designing sets of SDIs in Vietnam, which assures the comprehensibility and adequacy of sustainable development relying on the theme-based framework of the United Nations, and comes with the software for the calculation of indicator values and effectively tracking, monitoring, and evaluating sustainable development in the provinces. The approach can be applied for designing sets of SDIs in Vietnam to provide a scientific basis for the Vietnam government to modify the promulgated sets of SDIs.

The experiences gained when developing the procedure and methods which resulted in a set of SDIs for Tay Nguyen could be applied for designing VSDGIs in the future. 
Acknowledgments: The authors would like to thank the National Science and Technology Program for sustainable development of the Tay Bac region (project code: KHCN-TB.25X/13-18) for its support during preparing this paper. We would like to express our gratitude to Simon Watkinson who reviewed the English of the manuscript.

Author Contributions: Tri Ngo Dang was responsible for providing, reviewing SDIs, MDGIs/SDGIs, and giving ideals to edit the paper. Chi Tran Thuy and Y. Tran Van were responsible for providing and reviewing SDIs, SDGIs. Y. Tran Van was responsible for giving ideals to edit the paper. Tuan Nguyen Thanh designed the paper, created an outline, and maintained the direction of the paper. Tuan Nguyen Thanh was responsible for revising SDIs, MDGIs/SDGIs and integrating the ideals from the authors.

Conflicts of Interest: The authors declare no conflict of interest. The funding sponsor supported the design of the study, in the collection and analyses, interpretation of literatures, and in the writing of the manuscript.

\section{Appendix A}

Table A1. Set of sustainable development indicators designed the project "Implementation of Vietnam Agenda 21-VIE/01/021".

\begin{tabular}{|c|c|}
\hline Pillar & Indicator \\
\hline Economic & $\begin{array}{l}\text { GDP per capita (USD; VND) } \\
\text { GDP growth }(\%) \\
\text { The economic structure (\%) } \\
\text { Share of women employment in the agricultural sector }(\%) \\
\text { Investment share in GDP }(\%) \\
\text { ODA and FDI share in total investment }(\%) \\
\text { Gross domestic expenditure on R\&D as a percent of GDP }(\%) \\
\text { Gross domestic expenditure on education as a percent of GDP }(\%) \\
\text { Balance import and export goods (USD; VND) } \\
\text { Debt to GDP ratio }(\%) \\
\text { Annual energy consumption/GDP } \\
\text { Ratio of waste recycle }\end{array}$ \\
\hline Social & $\begin{array}{l}\text { Total population(millions population) } \\
\text { Proportion of population living below national poverty line }(\%) \\
\text { GINI index } \\
\text { Ratio of man salary to woman }(\%) \\
\text { Maternal Mortality Rate }(\%) \\
\text { Under-five malnutrition rate }(\%) \\
\text { Unemployment ratio in urban }(\%) \\
\text { Average life expectancy (Year) } \\
\text { Proportion of population using an improved water source }(\%) \\
\text { Adult literacy rate }(\%) \\
\text { Rate of Adult secondary schooling attainment level }(\%) \\
\text { College student per } 1000 \text { population }(0 / 00) \\
\text { Rate of educated labor }(\%) \\
\text { Proportion of population assessing modern communication technologies }(\%) \\
\text { Average square of house per population(m }{ }^{2} / \text { người) } \\
\text { Ratio of criminal per } 100,000 \text { population } \\
\text { Ratio of traffic accident per } 100,000 \text { population }\end{array}$ \\
\hline
\end{tabular}


Table A1. Cont.

\begin{tabular}{|c|c|}
\hline Pillar & Indicator \\
\hline Environmental & $\begin{array}{l}\text { Ratio of land area covered by forests (\%) } \\
\text { Portation of irrigate agriculture land (\%) } \\
\text { Portation of nature conservation forest (\%) } \\
\text { Rate of degaradation soil (\%) } \\
\text { Ratio of mine ores } \\
\text { Ratio of industrial zone own waste treatment systems (\%) } \\
\text { Number of business achieved ISO } 14001(\%) \\
\text { Emissions of greenhouse gases (tấn/năm) } \\
\text { Ratio of urban area that pollution concentration in the air exceeds Vietnamese standards } \\
\text { Number of threatened ecology systems and extinct species } \\
\text { Product yield of fishery (1000 ton) } \\
\text { Human and economic loss due to natural disasters }\end{array}$ \\
\hline Institutional & $\begin{array}{l}\text { Number of provinces built Agenda } 21 \\
\text { Number of offices and number of employees activity in sustainable development field } \\
\text { Mobilizing financial resources for hunger eradication and poverty reduction: The ODA invest } \\
\text { to hunger elimination and poverty reduction }\end{array}$ \\
\hline
\end{tabular}

Sources: (UNDP and MPI 2006).

\section{Appendix B}

Table A2. National set of sustainable development indicators for monitoring and assessing Vietnam sustainable development period 2011-2020.

\begin{tabular}{|c|c|c|}
\hline Indicators & 2015 & 2020 \\
\hline \multicolumn{3}{|l|}{ COMPOSITE INDEX } \\
\hline Green GDP (VND or USD) & - & - \\
\hline HDI $(0-1)$ & $\begin{array}{l}\text { Achievement of the } \\
\text { world's average }\end{array}$ & $\begin{array}{l}\text { Achievement of the } \\
\text { world's high average }\end{array}$ \\
\hline Sustainability Environment Index $(0-1)$ & ECONOMIC & - \\
\hline ICOR & $<5.0$ & $<5.0$ \\
\hline Productivity of social labour (USD/employee) & $3900-4000$ & $6100-6500$ \\
\hline Share of total factor productivity in growth rate & 30.0 & 35.0 \\
\hline $\begin{array}{l}\text { Reduction of energy consumption to produce one unit of gross } \\
\text { domestic product }\end{array}$ & $2.5-3 \% /$ year & $2.5-3 \% /$ year \\
\hline Share of renewable energy sources in total energy use (\%) & 4 & 5 \\
\hline CPI (\% compare to last 12 months) & Average of 5 years $<10$ & Average of 5 years $<5$ \\
\hline Drawing account (bilions USD) & -3.1 & $<-3.0$ \\
\hline State budget deficit over GDP (\%/GDP) & 4.5 & $<4.0$ \\
\hline Government dept (\%/GDP) & $60-65$ & $<55.0$ \\
\hline $\begin{array}{l}\text { Foreign dept (\%/GDP) } \\
\text { SOCIAL }\end{array}$ & $<50.0$ & $<50.0$ \\
\hline Proportion of population living below national poverty line (\%) & $\begin{array}{l}\text { Average reduction } \\
1.5-2 \% / \text { year }\end{array}$ & $\begin{array}{l}\text { Average reduction } \\
1.5-2 \% / \text { year }\end{array}$ \\
\hline Ratio of unemployment to population in working age (\%) & $<3.00$ & $<3.00$ \\
\hline Proportion of educated employee (\%) & 55 & $>70$ \\
\hline GINI index & $<5.0$ & $<5.0$ \\
\hline Sex ratio at birth (boys/100 girls) & 113 & 115 \\
\hline Ratio of student per 10000 population & 300 & 450 \\
\hline Internet users per 100 population & 8.5 (Big bandwidth) & 20 (Big bandwidth) \\
\hline $\begin{array}{l}\text { Proportion of people enjoying social insurance, health insurance } \\
\text { and unemployment insurance }(\%)\end{array}$ & $\begin{array}{c}\text { Social: } 38 \\
\text { Health: } 75 \\
\text { Unemployment: } 73\end{array}$ & $\begin{array}{l}\text { Social: } 51 \\
\text { Health: } 80 \\
\text { Unemployment: } 84.5\end{array}$ \\
\hline Number of deaths due to traffic acidents per 100,000 population & 11 & 9 \\
\hline $\begin{array}{l}\text { Proportion of communes achieve the standart of new } \\
\text { rural criteria }\end{array}$ & 20 & 50 \\
\hline
\end{tabular}


Table A2. Cont.

\begin{tabular}{|c|c|c|}
\hline Indicators & 2015 & 2020 \\
\hline \multicolumn{3}{|l|}{ ENVIRONMENTAL } \\
\hline Proportion of land area covered by forests (\%) & $42-43$ & 45 \\
\hline Proportion of protected land and maintained biodiversity land & - & - \\
\hline Area of degradation land (milions ha) & - & - \\
\hline Use of groundwater and surface water $\left(\mathrm{m}^{3} /\right.$ persion/year $)$ & - & 1770 \\
\hline $\begin{array}{l}\text { Ratio of days which pollution concentration in the air exceeds } \\
\text { Vietnamese standards in a year (\%) }\end{array}$ & - & - \\
\hline $\begin{array}{l}\text { Ratio of industrial zone, manufacturing area own waste } \\
\text { treatment systems that meets Vietnamese standards (\%) }\end{array}$ & 60 & 70 \\
\hline $\begin{array}{l}\text { The ratio of solid waste collected and treated meets Vietnamese } \\
\text { standard }(\%)\end{array}$ & 85 & 90 \\
\hline
\end{tabular}

Sources: (VPM 2012).

\section{Appendix C}

Table A3. Local set of sustainable development indicators for monitoring and assessing Vietnam sustainable development period 2013-2020.

\begin{tabular}{|c|}
\hline I. GENENERAL INDICATORS \\
\hline Indicator name \\
\hline COMPOSITE INDEX \\
\hline Human Development Index \\
\hline \multirow{2}{*}{$\begin{array}{l}\text { ECONOMIC } \\
\text { The ratio of investment for development to GDP (\%) }\end{array}$} \\
\hline \\
\hline \multirow{7}{*}{$\begin{array}{l}\text { ICOR } \\
\text { Productivity of social labour (milion VND per employee) } \\
\text { Ratio of budget revenue to budget expenditure (\%) } \\
\text { Area of rice land is protected and maintained (ha) } \\
\text { Uncompulsory indicator * } \\
\text { Share of total factor productivity in growth rate (\%) } \\
\text { Reduction of energy consumption to produce one unit of gross domestic product (\%) }\end{array}$} \\
\hline \\
\hline \\
\hline \\
\hline \\
\hline \\
\hline \\
\hline SOCIAL \\
\hline Proportion of poverty household (\%) \\
\hline Ratio of unemployment to population in working age (\%) \\
\hline Proportion of educated employee (\%) \\
\hline GINI index \\
\hline Sex ratio at birth (boys / 100 girls) \\
\hline Proportion of people paying social insurance, unemployment insurance and health insurance (\%) \\
\hline Ratio of budget expenditures for cultural and sport activities $(\%)$ \\
\hline Proportion of communes achieve the standart of new rural criteria (\%) \\
\hline Under-five mortality rate $(\%)$ \\
\hline Number of deaths due to traffic accidents per 100,000 population \\
\hline Ratio of pupils attending high school at the age (\%) \\
\hline ENVIRONMENTAL \\
\hline Proportion of population using an improved sanitation facility (\%) \\
\hline Proportion of protected land and maintained biodiversity land (\%) \\
\hline Area of degradation land (ha) \\
\hline $\begin{array}{l}\text { Ratio of urban, industrial zone, manufacturing area own waste treatment systems that meets Vietnamese } \\
\text { standards }(\%)\end{array}$ \\
\hline Proportion of land area covered by forests (\%) \\
\hline The ratio of solid waste collected and treated $(\%)$ \\
\hline Number of disasters and extent of damage (case, millions VND) \\
\hline Uncompulsory indicators * \\
\hline The proportion of mineral mining projects is performed environment recover (\%) \\
\hline Number of projects is built following Clean Development Mechanism (CDM) \\
\hline
\end{tabular}


Table A3. Cont.

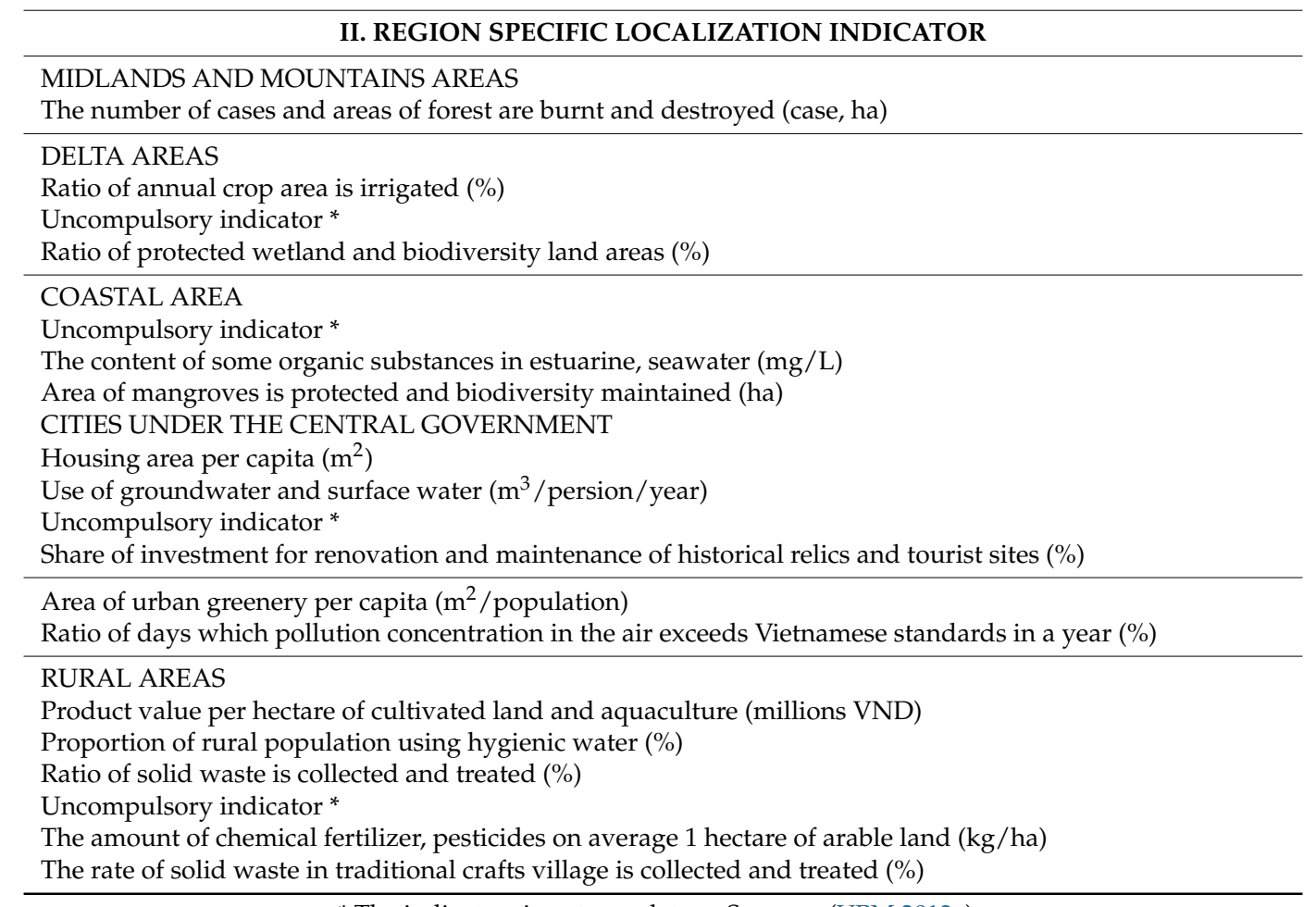

* The indicators is not mandatory, Sources: (VPM 2013a).

\section{Appendix D}

Table A4. The set of sustainable development indicators for monitoring and assessing sustainable development in Tay Nguyen's provinces.

\begin{tabular}{|c|c|c|}
\hline Theme & Subtheme & Indicators \\
\hline \multirow{8}{*}{ Economic development } & \multirow{4}{*}{ Macroeconomic performance } & GDP per capital (VND/person) \\
\hline & & Green GDP per capita (VND/person) \\
\hline & & Investment share in GDP (\%) \\
\hline & & Consumer Price Index (CPI) (\% compare to last 12 months) \\
\hline & \multirow{3}{*}{ Employment } & Ratio of unemployment to population to population (\%) \\
\hline & & $\begin{array}{l}\text { Ratio of minority unemployment to population to minority } \\
\text { population }(\%)\end{array}$ \\
\hline & & Productivity of social labour (milion VND per employee) \\
\hline & Tourism & Tourism contribution to GDP (\%) \\
\hline \multirow{2}{*}{ Global economic partnership } & \multirow{2}{*}{ External financing } & Rate of ODA to GDP (\%) \\
\hline & & Rate of FDI to GDP (\%) \\
\hline
\end{tabular}


Table A4. Cont.

\begin{tabular}{|c|c|c|}
\hline Theme & Subtheme & Indicators \\
\hline \multirow{8}{*}{$\begin{array}{l}\text { Consumption and } \\
\text { production patterns }\end{array}$} & $\begin{array}{l}\text { Material } \\
\text { consumption }\end{array}$ & $\begin{array}{l}\text { Product values obtained from } 1 \text { ha culitvating land per fertlizers weights } \\
\text { used for the land (VND/ha } / \mathrm{kg} \text { ) }\end{array}$ \\
\hline & \multirow{3}{*}{ Energy use } & $\begin{array}{l}\text { Number of kwh electricity use for agriculture-forestry-fishery/GDP in } \\
\text { agriculture-forestry-fishery (kw/millions VND) }\end{array}$ \\
\hline & & $\begin{array}{l}\text { Number of kwh electricity use for industry-construction/GDP in } \\
\text { industry-construction (kw/millions VND) }\end{array}$ \\
\hline & & $\begin{array}{l}\text { Number of kwh electricity use for trade-tourist-service/GDP in } \\
\text { trade-tourist-service (kw/millions VND) }\end{array}$ \\
\hline & \multirow{2}{*}{$\begin{array}{l}\text { Waste generation } \\
\text { and management }\end{array}$} & $\begin{array}{l}\text { The proportion of treated hazardous wastes meets the Vietnamese standard } \\
(\%)\end{array}$ \\
\hline & & $\begin{array}{l}\text { The proportion of collected, treated solid wastes meets the Vietnamese } \\
\text { standar }(\%)\end{array}$ \\
\hline & \multirow[t]{2}{*}{ Transportation } & $\begin{array}{l}\text { Percentage of passengers transported by road / total passenger } \\
\text { transport }(\%)\end{array}$ \\
\hline & & Percentage of goods transported by road / total freight (\%) \\
\hline \multicolumn{3}{|l|}{ 2. SOCIAL } \\
\hline \multirow{8}{*}{ Poverty } & \multirow{2}{*}{ Income poverty } & Rate of poverty in rural (\%) \\
\hline & & Rate of poverty in Ethnic community (\%) \\
\hline & $\begin{array}{l}\text { Income } \\
\text { inequality }\end{array}$ & GINI index \\
\hline & Sanitation & Proportion of rural households having hygienic toilet (\%) \\
\hline & \multirow{2}{*}{ Drinking water } & Proportion of urban population is provided clean water $(\%)$ \\
\hline & & Proportion of rural population is provided hygienic water (\%) \\
\hline & $\begin{array}{l}\text { Access to } \\
\text { energy }\end{array}$ & Proportion of rural households using electricity for daily life (\%) \\
\hline & $\begin{array}{l}\text { Living } \\
\text { conditions }\end{array}$ & $\begin{array}{l}\text { Proportion of urban households living at home is lacking in solidarity and } \\
\text { simplicity (\%) }\end{array}$ \\
\hline \multirow[t]{2}{*}{ Governance } & Corruption & $\begin{array}{l}\text { Number of defendants who are officials, civil servan cadres and civil } \\
\text { servants/1000 cadres and civil servants }\end{array}$ \\
\hline & Crime & Number of defendants/10,000 population \\
\hline \multirow{12}{*}{ Health } & \multirow{2}{*}{ Mortality } & Under-five mortality rate (\%) \\
\hline & & Under-five mortality rate in ethnic community (\%) \\
\hline & \multirow{4}{*}{$\begin{array}{l}\text { Health care } \\
\text { delivery }\end{array}$} & Proportion of hospital beds per 10,000 population \\
\hline & & Proportion of doctors per 10,000 populations ( $\%$ ) \\
\hline & & Immunization against infectious childhood diseases (\%) \\
\hline & & $\begin{array}{l}\text { Immunization against infectious childhood diseases in ethnic } \\
\text { community }(\%)\end{array}$ \\
\hline & \multirow{2}{*}{$\begin{array}{l}\text { Nutritional } \\
\text { status }\end{array}$} & Under-five malnutrition rate $(\%)$ \\
\hline & & Under-five malnutrition rate in ethnic community (\%) \\
\hline & \multirow{4}{*}{$\begin{array}{l}\text { Health status } \\
\text { and risks }\end{array}$} & Malaria death rate per 10,000 populations (\%) \\
\hline & & Malaria death rate per 10,000 population ethnic community (\%) \\
\hline & & Ratio of HIV infected people per 10,000 populations (\%) \\
\hline & & Average life expectancy (năm) \\
\hline \multirow{5}{*}{ Education } & \multirow{3}{*}{ Education level } & Percentage of pupils completing primary school (\%) \\
\hline & & Ratio of enrolment rate in primary education (\%) \\
\hline & & Adult tertiary schooling attainment level (\%) \\
\hline & Literacy & Adult literacy rate $(\%)$ \\
\hline & Culture & Rate of villages achieve Vietnamese standard in culture (\%) \\
\hline \multirow{2}{*}{ Demographics } & \multirow{2}{*}{ Population } & Natural population growth rate $(\%)$ \\
\hline & & Net-emigration rate $(\%)$ \\
\hline
\end{tabular}


Table A4. Cont.

\begin{tabular}{|c|c|c|}
\hline Theme & Subtheme & Indicators \\
\hline \multicolumn{3}{|c|}{ 3. ENVIRONMENTAL } \\
\hline \multirow{3}{*}{ Natural hazards } & $\begin{array}{l}\text { Vulnerability to } \\
\text { natural hazards }\end{array}$ & Percentage of population living in hazard prone areas (\%) \\
\hline & \multirow{2}{*}{$\begin{array}{l}\text { Disaster preparedness } \\
\text { and response }\end{array}$} & Human loss due to natural disasters per 10,000 populations (\%) \\
\hline & & Economic loss due to natural disasters/GDP(\%) \\
\hline \multirow{5}{*}{ Atmosphere } & Climate change & Carbon dioxide emissions in industry area \\
\hline & \multirow{4}{*}{ Air quality } & $\begin{array}{l}\text { Sample rate of dust content in air at specific place exceeds Vietnamese } \\
\text { standards }(\%)\end{array}$ \\
\hline & & $\begin{array}{l}\text { Sample rate of } \mathrm{SO}_{2} \text { content in air at specific place exceeds Vietnamese } \\
\text { standards (\%) }\end{array}$ \\
\hline & & $\begin{array}{l}\text { Sample rate of } \mathrm{NO}_{2} \text { content in air at specific place exceeds Vietnamese } \\
\text { standards }(\%)\end{array}$ \\
\hline & & $\begin{array}{l}\text { Sample rate of noise level in air at specific place exceeds Vietnamese } \\
\text { standards (\%) }\end{array}$ \\
\hline \multirow{9}{*}{ Land } & \multirow{3}{*}{ Land use and status } & Rate of change of agricultural land (after 5 years) (\%) \\
\hline & & Rate of change of forest land (after 5 years) $(\%)$ \\
\hline & & Erosion (ton/ha/year) \\
\hline & Desertification & Ratio of heavy drought area (SPI) <-1.5) $(\%)$ \\
\hline & \multirow{2}{*}{ Agriculture } & Proportion of annual agricultural land area / suitable cultivated area (\%) \\
\hline & & Rate of irrigated agricultural land (\%) \\
\hline & \multirow{3}{*}{ Forests } & Proportion of natural forest area / land area to be protected (\%) \\
\hline & & $\begin{array}{l}\text { Percentage of plantaion forest and perennial industrial crops / area of land } \\
\text { suitable for development of production forest }(\%)\end{array}$ \\
\hline & & Area of forest under sustainable forest management (\%) \\
\hline \multirow{4}{*}{ Freshwater } & \multirow{2}{*}{ Water quantity } & Proportion of total water resources used (\%) \\
\hline & & Water use intensity by economic activity /GDP (l/VNĐ) \\
\hline & \multirow{2}{*}{ Water quality } & $\begin{array}{l}\text { Sample rate of Feacal Coliform analysis in surface water at specific sites } \\
\text { exceeds Vietnamese standards }(\%)\end{array}$ \\
\hline & & $\begin{array}{l}\text { Sample rate of BOD analysis in surface water at specific sites exceeds } \\
\text { Vietnamese standards }(\%)\end{array}$ \\
\hline \multirow{7}{*}{ Biodiversity } & \multirow{4}{*}{ Ecosystem } & Proportion of conservation area/natural forest area (\%) \\
\hline & & Rate of change of Dipterocarp forest ecosystem (\%) \\
\hline & & Rate of change in area of evergreen broad-leaved forest ecosystem (\%) \\
\hline & & Fragmentation of habitats \\
\hline & \multirow{3}{*}{ Species } & $\begin{array}{l}\text { Rate of change in numbers of taxa on the threat level of these taxa in the } \\
\text { Red Book }(\%)\end{array}$ \\
\hline & & Rate of endemic species of Central Highlands/total species in Vietnam (\%) \\
\hline & & Proportion of exotic species entering the Central Highlands (\%) \\
\hline
\end{tabular}

Sources: (Tran Van et al. 2016).

\section{References}

Côté, Amélie, and Dick McCollough. 2007. Comparative Analysis of Indicator Systems for Sustainable Development; Québec: The Office for the Coordination of Sustainable Development of the Ministry of Sustainable Development, Environment and Parks.

Vietnam General Statistics Office (GSO). 2005. Vietnam Development Data 1990-2003; Ha Noi: GSO, 13 p.

Hai, Le Trinh, Hai Pham Hoang, Khoa Nguyen Trương, and Hens Luc. 2009. Indicators set for sustainable development indicators: A case study in the province of Quang Tri, Vietnam. International Journal of Human Ecology 27: 217-27. [CrossRef]

Hai, Le Trinh, Hai Pham Hoang, Ha Pham Thi Thu, Ha Nguyen Manh, Dai Ly Trong, Hoa Pham Viet, Huan Nguyen Cao, and Cam Lai Vinh. 2013. A system of sustainability indicators for the province of Thai Binh, VietNam. Social Indicators Research 116: 661-79. [CrossRef] 
ICLEI-Local Governments for Sustainability (ICLEI). 2015. From MDGs to SDGs: What are the Sustainable Development Goals? Available online: www.iclei.org/publications (accessed on 5 December 2017).

International Institue for Sustainable Development (IISD). 2017. Compendium of Sustainable Development Indicator Initiatives and Publications [cited 4/2017]. Available online: http:/ / www.iisd.org/measure/ compendium/searchinitiatives.aspx (accessed on 15 April 2017).

Lam, Nguyen Tung. 2015. International Lessons on Designing Environmental Performance Index and Applicability in Vietnam. Journal Science and Technology Policy and Management 4: 62-76.

Lam Dong Provincial People's Committee (Lam Dong). 2006. Sustainable Development Strategy of Lam Dong Province Period 2006-2010 and Vision 2020; Ha Noi: Publisher of Society and Labours.

Lock, Graham. 2006. Experience in the Elaboration and Use of Sustainable Development Indicators for the European Union. Paprer Submitted to the Workshop on Sustainable Development Indicators at Université Laval, June; Laval: Université Laval.

Maya, Fehling, Brett D. Nelson, and Sridhar Venkatapuram. 2013. Limitations of the Millennium Development Goals: A literature review. Global Public Health 8: 1109-22.

Vietnam Ministry of Planning and Investment (MPI). 2005. The Circular Letter No 01/2005/TT-BKH on Implementation of Vietnam Prime Minister's Decision on Vietnam Agenda 21; Ha Noi: MPI.

Vietnam Ministry of Planning and Investment (MPI). 2013. The Circular Letter No 02/2013/TT-BKHĐT on Guidelines of Implementation Some Contents of Vietnam Sustainable Development Strategy Period 2011-2020; Ha Noi: MPI.

Nathan, Hippu Salk Kristle, and B. Sudhakara Reddy. 2008. A Conceptual Framework for Development of Sustainable Development Indicators. Working Paper WP-2008-003; Maharashtra, India: Indira Gandhi Institute of Development Research (IGIDR).

Ninh Binh Provincial People's Committee (Ninh Binh). 2006. Sustainable Development Strategy of Yen Bai Province Period 2006-2010 and Vision 2020; Ha Noi: Con Duong Moi Limited Liability Company.

Peterson, P. J. 1997. Indicators of Sustainable Development in Industrializing Countries. Hulu Langat District: Lestari Publishers.

Quang Nam Provincial People's Committee (Quang Nam). 2006. Sustainable Development Strategy of Quang Nam Province Period 2006-2010 and Vision 2020; Ha Noi: Con Duong Moi Limited Liability Company.

Thai Nguyen Provincial People's Committee (Thai Nguyen). 2006. Sustainable Development Strategy of Thai Nguyen Province Period 2006-2010 and Vision 2020; Ha Noi: Publisher of Society and Labours.

Tran Van, Y, Thinh Nguyen Viet, Tuan Nguyen Thanh, Tri Ngo Dang, Chi Tran Thuy, Chinh Nguyen The, and Hau Nguyen Xuan. 2016. Tay Nguyen Sustainable Development: Assessment and Solutions. Ha Noi: Publisher of Vietnam Natural Science and Technology.

Tuan, Vu Duy. 2015. Emphasizing Natural Capital in the Greater Mekong Subregion. Paper presented at International Conference on Sustainable Development, New York, NY, USA, September 23-24.

United Nations Commission on Sustainable Development (UNCSD). 1996. Indicators of Sustainable Development Framework and Methodologies. New York: Division for Sustainable Development.

United Nations Commission on Sustainable Development (UNCSD). 2001. Indicators of Sustainable Development: Framework and Methodologies. New York: Division for Sustainable Development.

United Nations Commission on Sustainable Development (UNCSD). 2007. Indicators of Sustainable Development Framework and Methodologies. New York: Division for Sustainable Development.

United Nations Development Programme (UNDP), and The Vietnam Ministry of Planning and Investment (MPI). 2006. Identification of a Sustainable Development Indicators Set and Mechanism for Building a Sustainable Development Database in Vietnam; Ha Noi: Publisher of Society and Labours.

United Nations. 1992. Agenda 21. Paper presented at Conference on Environment and Development, Rio de Janerio, Brazil, June 3-14.

United Nations Statistical Commission (UNSC). 2017. Report of the Inter-Agency and Expert Group on Sustainable Development Goal Indicators (E/CN.3/2017/2). New York: The United Nations.

Socialist Republic of Vietnam (VN). 2012. Implementation of Sustainable Development-National Report at the United Nations Conference on Sustainable Development (RIO + 20); Ha Noi: Kimdo Trading and Marketing Co., Ltd.

Socialist Republic of Vietnam (VN). 2015. The Country Report on 15 Years Achieving the Vietnam Millennium Development Goals; Ho Chi Minh: Joint Stock \& Truong an Commercial Company, 148 p.

Vietnam Prime Minister (VPM). 2005. Decision No 1032/QĐ-TTg of Vietnam Prime Minister on Foundation of the National Sustainable Development Council; Ha Noi: VPM. 
Vietnam Prime Minister (VPM). 2012. Decision No 432/QĐ-TTg of Vietnam Prime Minister on Promulgation of the Vietnam Sustainable Development Strategy Period 2011-2020; Ha Noi: VPM.

Vietnam Prime Minister (VPM). 2013a. Decision No 2157/QĐ-TTg of Vietnam Prime Minister on Promulgation of Local Set of Sustainable Development Indicators; Ha Noi: VPM.

Vietnam Prime Minister (VPM). 2013b. Decision No. 1755/QĐ-TTg on "Principles and Tasks for Reporting on the Implementation of MDGs"; Ha Noi: VPM.

Vietnam Prime Minister (VPM). 2014. Resolution 05/NQ-CP on Accelerating the Implementation of the MDGs for the Health Sector; Ha Noi: VPM.

Vietnam Prime Minister (VPM). 2017. Decision No 622/QĐ-TTg on National Action Plans to Implement the Agenda 2030 for the Sustainable Development; Ha Noi: VPM.

Vietnam Agenda 21 Office (VPPTBV). 2013. The Workshop on Training of the Local Set of Sustainable Development Indicators. Available online: http:/ / va21.gov.vn/baiviet.aspx?id=415 (accessed on 24 July 2013).

Vietnam Agenda 21 Office (VPPTBV). 2014. Report on the Local Set of Sustainable Development Indicators period 2013-2020. Available online: http:/ / va21.gov.vn/baiviet.html?id=436 (accessed on 24 July 2013).

Vietnam Agenda 21 Office (VPPTBV). 2016. The Report on Studying, Reviewing 17 Goals and 169 Targets in the Agenda 30 for Sustainable Development in Vietnam, Providing Bases for Nationalization of Global SDGs; Ha Noi: The Vietnam Ministry of Planning and Investment.

Vuong, Nguyen Van. 2016. Studying, Designing an Interdisciplinary Database System for Sustainable Development in the North West Region. National Science and Technology Program "Science and Technology for Sustainable Development in the North West Region"; Washington: National Academies Press.

Yen Bai Provincial People's Committee (Yen Bai). 2006. Agenda 21 on Sustainable Development of Yen Bai Province Yen Bai; Yen Bai City: Yen Bai Provincial People's Committee.

(C) 2017 by the authors. Licensee MDPI, Basel, Switzerland. This article is an open access article distributed under the terms and conditions of the Creative Commons Attribution (CC BY) license (http:/ / creativecommons.org/licenses/by/4.0/). 